\title{
Rapid deepening of tropical cyclones in the northeastern Tropical Pacific: The relationship with oceanic eddies
}

\author{
FERNANDO OROPEZA and GRACIELA B. RAGA \\ Centro de Ciencias de la Atmósfera, Universidad Nacional Autónoma de México, Circuito de la Investigación \\ Cientifica s/n, Ciudad Universitaria, 04510 México, D.F. \\ Corresponding author: F. Oropeza; e-mail: foropeza@fugro.com
}

Received March 27, 2014; accepted October 13, 2014

\begin{abstract}
RESUMEN
Los datos del archivo de trayectorias mejoradas (best track) del Centro Nacional de Huracanes de Miami para el Pacífico nororiental tropical incluyen ciclones tropicales (CT) que exhiben profundización rápida y/o explosiva durante el periodo 1993-2009. Al mismo tiempo, observaciones de altimetría satelital muestran al Pacífico nororiental tropical poblado por remolinos oceánicos ciclónicos y anticiclónicos. Estas dos fuentes de datos se utilizan para estudiar el papel de los remolinos oceánicos en la distribución espacial del calor oceánico y la profundización rápida y/o explosiva de los CT del Pacífico nororiental tropical. El análisis de los resultados demuestra que: 1) la interacción entre CT y remolinos oceánicos anticiclónicos ocurrió en $\sim 73 \%$ de los CT del periodo analizado; 2) de los CT que alcanzaron la categoría de huracanes, 90\% había interaccionado con los remolinos oceánicos anticiclónicos; 3) 18\% (3\%) de los CT se caracterizaron por profundización rápida (explosiva), 74\% de éstos alcanzaron el estado de profundización después de su interacción directa y/o indirecta con remolinos oceánicos anticiclónicos, y de ellos el $86 \%$ alcanzó la categoría de huracán mayor. El análisis de las condiciones atmosféricas demuestra que la intrusión de aire seco a lo largo del perfil vertical de la atmósfera inferior desempeñó un papel importante como inhibidor de la profundización.
\end{abstract}

\begin{abstract}
The National Hurricane Center best track archive data for the northeastern Tropical Pacific includes tropical cyclones (TC) that exhibited rapid and/or explosive deepening during the period 1993-2009. Concurrently, satellite altimeter observations show the northeastern Tropical Pacific populated by cyclonic and anticyclonic oceanic eddies. These two sources of data are used to study the role of oceanic eddies in the spatial distribution of the oceanic heat content and the rapid and/or explosive deepening of TCs in the northeastern Tropical Pacific. Analysis of the results demonstrates that: (1) Interaction between TCs and anticyclonic eddies occurred in $\sim 73 \%$ of the TCs within the analyzed period; (2) $90 \%$ of the TCs that reached major hurricane category had experienced an interaction with anticyclonic eddies; (3) 18\% (3\%) of the TCs were characterized by rapid (explosive) deepening and $74 \%$ of these TCs reached the deepening status after direct and/or indirect interaction with anticyclonic eddies; moreover, $86 \%$ of them reached a major hurricane category. Analysis of the atmospheric conditions demonstrates the important role of dry air intrusion along the vertical profile of the lower atmosphere as an inhibitor of tropical cyclone deepening.
\end{abstract}

Keywords: Tropical cyclones, oceanic eddies, rapid deepening.

\section{Introduction}

The glossary of the National Weather Service of the National Oceanic and Atmospheric Administration (NOAA) (http://forecast.weather.gov/glossary.php) defines rapid deepening (RD) of a tropical cyclone (TC) as a decrease in its minimum sea-level pressure of $1.75 \mathrm{hPa} / \mathrm{h}$ or $42 \mathrm{hPa}$ during 24 hours. Explosive deepening (ED) occurs in a cyclone when the 
central pressure decreases $2.5 \mathrm{hPa} / \mathrm{h}$ for at least $12 \mathrm{~h}$ or $5 \mathrm{hPa} / \mathrm{h}$ for at least $6 \mathrm{~h}$. Such changes in the structure of a TC can be associated to large-scale atmospheric forcing (e.g., advection of moisture that may protect individual convective towers and/or reduction in the vertical shear of the horizontal wind, among others) and as recent studies have suggested, to mesoscale oceanic features.

While the oceans have been recognized as the energy source for hurricanes for more than half a century (Palmen, 1948; Fisher, 1958; Leipper, 1967; Perlroth, 1967), subsequent studies indicate that the maximum hurricane intensity was constrained by thermodynamic effects principally related to the sea surface temperature (SST) (Miller, 1958; Emanuel, 1986). More recent studies for hurricanes Katrina and Rita (Jaimes and Shay, 2009) showed that decreases of the sea-level pressure were better correlated with the large depth of the $26^{\circ} \mathrm{C}$ isotherm and the ocean heat content (OHC) than the SSTs, which were essentially uniform for those cases. The concept of $\mathrm{OHC}$ was originally defined by Leipper and Volgenau (1972).

Over the last decades, several studies have highlighted the interactions between ocean features and TC evolution in several cyclogenetic basins. During the 1995 North Atlantic tropical cyclone season, hurricane Opal (the most intense in that season) experienced a sudden and unpredicted intensification $24 \mathrm{~h}$ before its landfall. During the rapid deepening from 965 to $916 \mathrm{hPa}$ over $14 \mathrm{~h}$, Opal moved over an anticyclonic oceanic eddy that had been shed from the Loop Current in the Gulf of Mexico (Hong et al., 2000). After the interaction with the eddy, the 1-min surface winds increased from 35 to more than $60 \mathrm{~ms}^{-1}$ and the radius of maximum winds decreased from 40 to $25 \mathrm{~km}$ (Shay et al., 2000).

In the western North Pacific, supertyphoon Mae$\mathrm{mi}$ (the most intense of the 2003 season) intensified (in 1-min sustained wind) from 41 to its peak of $77 \mathrm{~ms}^{-1}$ during its $36 \mathrm{~h}$ interaction with an anticyclonic oceanic eddy. Lin et al. (2005) demonstrated that the anticyclonic oceanic eddy acts as an effective insulator between the typhoon and the deeper ocean cold water, inhibiting the effect of the negative feedback (Chang and Anthes, 1978) between the ocean and the typhoon.

Hurricanes Katrina and Rita (the third and second most intense cyclones of the 2005 North Atlantic season) experienced rapid deepening during their respective encounter with an anticyclonic oceanic eddy in the Gulf of Mexico. Jaimes and Shay (2009) have studied these cases using a variety of datasets to evaluate the rapid increase in intensity observed during their respective passages over mesoscale oceanic features such as an anticyclonic oceanic eddy and the Loop Current. The authors conclude that in each case the observed decrease in central pressure correlated better with the depth of the $26^{\circ} \mathrm{C}$ isotherm and the $\mathrm{OHC}$ relative to this isotherm than with the SST.

The presence of oceanic eddies has a direct impact in the vertical structure of the near-surface oceanic layers, modifying the structure of the energy source for TCs. In the northern hemisphere, the anticyclonic horizontal flow of a geostrophically balanced eddy induces a secondary circulation directed towards the center of the gyre, producing a high pressure region in the surface, which also increases the depth of the thermocline. The result is a local pool with $\mathrm{OHC}$ higher than the surrounding waters. Such a local pool of high $\mathrm{OHC}$ could constitute a localized heat source to tropical cyclones. These warm features are characterized by isotherms displaced downward by several meters at the center of the eddy; in regions like the Gulf of Mexico, the depth of the $26^{\circ} \mathrm{C}$ isotherm can extend to more than $100 \mathrm{~m}$, providing a continuous source of heat for tropical cyclones to intensify under favorable atmospheric conditions (Hong et al., 2000; Shay et al., 2000). Conversely, a geostrophically balanced eddy with cyclonic horizontal flow induces a secondary circulation directed towards the periphery of the gyre, producing a low-pressure region at the center of the gyre in the surface, which reduces the depth of the thermocline and generates a local pool with $\mathrm{OHC}$ lower than the surrounding environment. TCs interaction with cyclonic oceanic eddies can also have an impact by weakening their intensity, as it has been discussed by Jaimes and Shay (2009), but in this study we will solely focus on interactions with anticyclonic oceanic eddies.

Chelton et al. (2011) analyzed 16 years of sea-surface height (SSH) fields from satellite altimeters to investigate mesoscale variability in the global ocean, revealing that more than $50 \%$ of the variability is accounted for by westward-propagating nonlinear mesoscale eddies. Such mesoscale variability is due to linear Rossby waves and nonlinear eddies (Chelton et al., 2007). In contrast to linear waves, 
nonlinear eddies can transport momentum, heat, mass and chemical constituents of seawater (Robinson, 1983). This study demonstrated that oceanic eddies are originated nearly everywhere in the world oceans. There is evidence that the relative vorticity is nearly constant within the interior of most eddies, i.e., the fluid motion is approximately in solid-body rotation. The observed eddies propagate nearly due west with small opposing meridional deflections of cyclones and anticyclones (poleward and equatorward, respectively).

Palacios and Bograd (2005) perform a statistical study of the activity of anticyclonic oceanic eddies in the northeastern Tropical Pacific basin between 1993 and 2004 and conclude that it is dominated by wind-generated eddies that originate in the gulfs of Tehuantepec and Papagayo. These eddies move westward away from the coast, within a band of latitude between $8^{\circ}$ and $15^{\circ} \mathrm{N}$, with horizontal dimensions ranging from 100 to over $400 \mathrm{~km}$ in diameter. These eddies maintain their intensity over several months (on average the eddy season begins in late October and ends in early July) and reach longitudes beyond $130^{\circ} \mathrm{W}$. Moreover, the total number of observed eddies presents a high inter-annual variability, with a minimum of three and a maximum of 13 per year. The number, intensity (in terms of its dynamic height and geostrophic circulation) and lifetime of eddies increase during El Niño years (e.g., El Niño 19971998 and 2002-2003).

Additional studies have analyzed and discussed the existence of anticyclonic oceanic eddies in different regions along the coast of the Mexican Pacific. Studies particularly relevant for interactions with tropical cyclones, have identified three other regions located further north than the Gulf of Tehuantepec: (1) the coast of Guerrero (Zamudio et al., 2001); (2) the coasts of Jalisco and Nayarit in the area of Cabo Corrientes and Marías Islands (Zamudio et al., 2007; Pantoja et al., 2012); and (3) the southern part of the Gulf of California (Kurczyn et al., 2012). These studies show the presence of anticyclonic oceanic eddies in those regions also during the hurricane season. Generation mechanisms proposed in those studies link the mesoscale eddies to the presence of equatorially-originated downwelling coastally-trapped waves that propagate poleward along the coast of the Mexican Pacific, its interaction with the pole- ward Mexican Coastal Current, and also baroclinic instabilities of the near-coastal currents.

To the best of our knowledge, no studies to date have explored the relationship between the presence of anticyclonic oceanic eddies in the northeastern Tropical Pacific and the evolution of tropical cyclones. In particular, we concentrate in this study on the contribution of those eddies to the spatial distribution of $\mathrm{OHC}$ and the rapid and/or explosive deepening of tropical cyclones in the region. Most of the scientific literature devoted to the analysis of hurricane-oceanic eddy interaction does not include the analysis of the atmospheric environmental parameters; it merely assumes favorable atmospheric conditions. In this study we also use a high-resolution regional reanalysis of atmospheric variables to study and understand the atmospheric context in which hurricane-oceanic eddy interactions occur and the potential role of those atmospheric conditions as deepening inhibitors. We address specifically the following questions:

1. Does the interaction between TCs and anticyclonic oceanic eddies occur in the northeastern Tropical Pacific basin? And if so, how often it occurs?

2. Is such an interaction a necessary condition for rapid or explosive deepening to occur during the evolution of TCs in the region?

3. Is such an interaction an important factor in the development of major hurricanes (e.g., categories 3,4 and 5) in the region?

4. Even in the presence of such an interaction, what is the relative role of atmospheric conditions in curtailing the deepening?

This paper has been organized in eight sections; section 2 is devoted to describe datasets used in this work, and section 3 describes the methodology to estimate $\mathrm{OHC}$ and evaluate the potential impact of anticyclonic oceanic eddies in its temporal and spatial distribution. A joint analysis of the best track dataset, $\mathrm{OHC}$ and satellite altimetry data is performed in section 4 , while in section 5 we identify periods of rapid and explosive deepening in TCs evolution. In section 6 we analyze the atmospheric environmental parameters to then review the relationship between the deepening of TCs and anticyclonic oceanic eddies in section 7. Concluding remarks are presented in section 8 . 


\section{Datasets}

In order to address the scientific questions that motivate this work, we made use of a variety of datasets: $(i)$ the best track information from the National Hurricane Center (NHC) (Davis et al., 1984); (ii) satellite altimetry products (produced by Ssalto/DUACS and distributed by Aviso with support from the Centre National d'Etudes Spatiales [http://www.aviso.oceanobs.com/duacs/]); (iii) The North American Regional Reanalysis (NARR) (Mesinger et al., 2005); (iv) the Generalized Digital Environmental Model (GDEM) from the U.S. Navy (Teague et al., 1990); (v) NOAA Optimum Interpolation SST (Reynolds et al., 2002); (vi) the SST from TRMM Microwave Imager (TMI) data (produced by Remote Sensing Systems and sponsored by the NASA Earth Science Measures Discover Project [data are available at http://www. remss.com]); and (vii) SST from the Advanced Microwave Scanning Radiometer-EOS (AMSR-E) data (produced by Remote Sensing Systems and sponsored by the NASA Earth Science Measures Discover Project and the AMSR-E Science Team [data are available at http://www.remss.com]).

\section{Estimating the ocean heat content}

Since we want to understand the role of anticyclonic oceanic eddies on the spatial distribution of $\mathrm{OHC}$ useful for TCs in the region (also referred as tropical cyclone heat potential), we need to calculate the $\mathrm{OHC}$ relative to the $26^{\circ} \mathrm{C}$ isotherm as defined by Leipper and Volgenau (1972):

$O H C=\rho_{w} C_{w} \int_{z=H_{26}}^{z=n^{\prime}}\left(T(z)-26^{\circ} \mathrm{C}\right) d z$

where $\rho_{w}$ is the average density of the upper ocean water $\left(1026 \mathrm{~kg} \mathrm{~m}^{-3}\right), C_{w}$ is the specific heat of seawater at constant pressure $\left(4178 \mathrm{~J} \mathrm{~kg}^{-1} \mathrm{~K}^{-1}\right), T(z)$ is the upper ocean temperature structure and $d z$ is the change in depth. Note that the reference temperature is $26{ }^{\circ} \mathrm{C}$, since it is the temperature assumed for tropical cyclogenesis (Palmen, 1948) and that the limits of the integral go from the depth of the $26^{\circ} \mathrm{C}$ isotherm $\left(H_{26}\right)$ to the elevation of the free surface $\left(\eta^{\prime}\right)$.

The calculation of the OHC requires the evaluation of the vertical temperature profile, and we use the approach proposed by Goni et al. (1996) and Shay et al. (2000) where the OHC is estimated using satellite altimetry and SST data in a two-layer reduced-gravity ocean model. In this scheme the upper and lower layers are separated by the depth of the $20^{\circ} \mathrm{C}$ isotherm and the reduced gravity is given by:

$g^{\prime}=\frac{g\left(\rho_{2}-\rho_{1}\right)}{\rho_{2}}$

where $g$ is the acceleration of gravity, $\rho_{1}$ represents the density of the upper layer and $\rho_{2}$ represents the density of the lower layer (O'Brien and Reid, 1967; Kundu, 1990; Goni et al., 1996). In this approach the total depth of the $20^{\circ} \mathrm{C}$ isotherm is given by:

$H_{20}=\overline{H_{20}}+\frac{g}{g^{\prime}} \eta^{\prime}$

where $\overline{H_{20}}$ represents the average depth of the $20{ }^{\circ} \mathrm{C}$ isotherm from climatology. Mainelli (2000) proposed that $\overline{H_{20}}$ should be determined only for the tropical cyclone season in the region (May through November) instead of an annual climatology, originally used in the approach of Goni and Trinanes (2003). In Eq. (3), $\eta^{\prime}$ is the sea surface height anomaly (SSHA) from satellite altimetry measurements. The total depth of the $26^{\circ} \mathrm{C}$ isotherm is determined from the relationship:

$H_{20}=\frac{\overline{H_{26}}}{\overline{H_{20}}} H_{20}$

where $\overline{H_{26}}$ is the average depth of the $26^{\circ} \mathrm{C}$ isotherm from the climatology determined over the tropical cyclone season only. The $\mathrm{OHC}$ is calculated in two stages. The first stage is determined from the climatological ocean mixed layer depth $(h)$, using the satellite-derived SST as a proxy for the temperature in the mixed layer. The $\mathrm{OHC}$ in the mixed layer up to the depth $h$ is proportional to $\left[\left(S S T-26^{\circ} \mathrm{C}\right) \times h\right]$. The second stage involves estimating the $\mathrm{OHC}$ in the layer underneath the mixed layer, from $h$ to the depth of the $26^{\circ} \mathrm{C}$ isotherm, and it is approximated as $0.5\left[H_{26}-h\right]\left[S S T-26{ }^{\circ} \mathrm{C}\right]$. The total OHC is then estimated as the sum of both contributions. Some underlying assumptions of this approach and detailed evaluation of satellite-inferred values to observed profiles for the northeastern Tropical Pacific are discussed by Shay and Brewster (2010).

We used the Generalized Digital Environmental Model (GDEM, version 3.0) climatology (3-D fields 
of temperature and salinity) from the U.S. Navy, to calculate the climatological values of $\rho_{1}$ and $\rho_{2}$ during the tropical cyclone season (May through November). We also used the GDEM to calculate the depths of the 20 and $26^{\circ} \mathrm{C}$ isotherms and climatological depth of the ocean mixed layer. In order to cover the complete period included in this study (1993-2009), three different sources of satellite-derived SST data were used, summarized in Table I. The sea surface height anomaly $\left(\eta^{\prime}\right)$ needed for the calculation of the $\mathrm{OHC}$ was obtained from the Ssalto/DUACS product that changed its periodicity from every seven days to daily in July 2006, with grid spacing of 20 arc minutes in a global coverage.

Daily maps of $\mathrm{OHC}$ were generated objectively analyzing the climatological parameters and the instantaneous maps of SST and SSHA to a regular grid with $0.125^{\circ}$ spacing in latitude-longitude, for the full period of our study. The resultant maps compare very well with those calculated by Shay and Brewster (2010). These regular grids were used to calculate: (a) the monthly climatology (1993-2009) of OHC during the tropical cyclone season of the northeastern Tropical Pacific (Fig. 1), and (b) the evolution of the 6-hourly instantaneous OHC along the track and life-time of each named TC in the best track database between 1993 and 2009 (this latter topic will be discussed in section 4).

Temporal and spatial variability of the $\mathrm{OHC}$ in the northeastern Tropical Pacific (Fig. 1) during the months that comprise the tropical cyclone season for this basin appears to be closely linked to the presence of oceanic mesoscale structures. During May and June, maximum values of $\mathrm{OHC}$ are concentrated between $100-110^{\circ} \mathrm{W}$ and $8-15^{\circ} \mathrm{N}$. This maximum is likely dominated by anticyclonic oceanic eddies that were windgenerated in the Gulf of Tehuantepec and the Gulf of Papagayo (Palacios and Bograd, 2005) and have propagated westwards towards the central Pacific. This feature has been identified by Kessler (2006) as a thermocline depression and has been named as the "Tehuantepec Bowl". Kessler (2006) has also reported that it weakens and retreats offshore during boreal summer. This feature appears to be a direct result of anticyclonic oceanic eddies activity in the region, but it still remains an open question for the oceanographic community. Note that the maximum values of $\mathrm{OHC}$ (above $80 \mathrm{~kJ} \mathrm{~cm}^{-2}$ ) are observed during May, at the beginning of the tropical cyclone season for this basin.

During mid-season months (July and August), the $\mathrm{OHC}$ appears to be dominated by a combination of the remnants of the Tehuantepec and Papagayo eddies and the arrival to the area of the downwelling coastally-trapped waves that originate at the equator. Zamudio et al. $(2001,2006)$ hypothesize that these waves can trigger anticyclonic oceanic eddies during its transit through different regions of the Pacific coast, from the Gulf of Papagayo to the Gulf of Tehuantepec and along the coast of the state of Guerrero.

The OHC values begin to decrease in September and October and the extension of high OHC areas starts to retract. The maximum values of $\mathrm{OHC}$ appear to be dominated almost completely by anticyclonic oceanic eddies generated along the coast of Guerrero, Jalisco and Nayarit in the area of the Marías Islands and Cabo Corrientes, likely triggered by equatorially-originated downwelling coastally-trapped waves that have already traveled more poleward (Zamudio et al., 2007) or by baroclinic instabilities of the near-coastal currents (Pantoja et al., 2012). These values probably also include the presence of eddies in the southern part of the Gulf of California that have been reported by Zamudio

Table I. Summary of satellite-derived sea surface temperature sources used in this study for various analyzed periods.

\begin{tabular}{lllll}
\hline Period & Product & Spatial resolution & Periodicity & Agency \\
\hline $1993-1997$ & SST-Reynolds & $1^{\circ}$ (long., lat.) & Weekly & NOAA \\
$1998-2001$ & TMI & $0.25^{\circ}$ (long., lat.) & Daily & REMSS/NASA \\
$2002-2009$ & AMSR-E & $0.25^{\circ}$ (long.,lat.) & Daily & REMSS/NASA \\
\hline
\end{tabular}

SST: sea surface temperature; TMI: Tropical Rainfall Measuring Mission's Microwave Imager; AMSR-E: Advanced Microwave Scanning Radiometer-EOS; NOAA: National Oceanic and Atmospheric Administration; REMSS/NASA: Remote Sensing Systems/ National Aeronautics and Space Administration. 

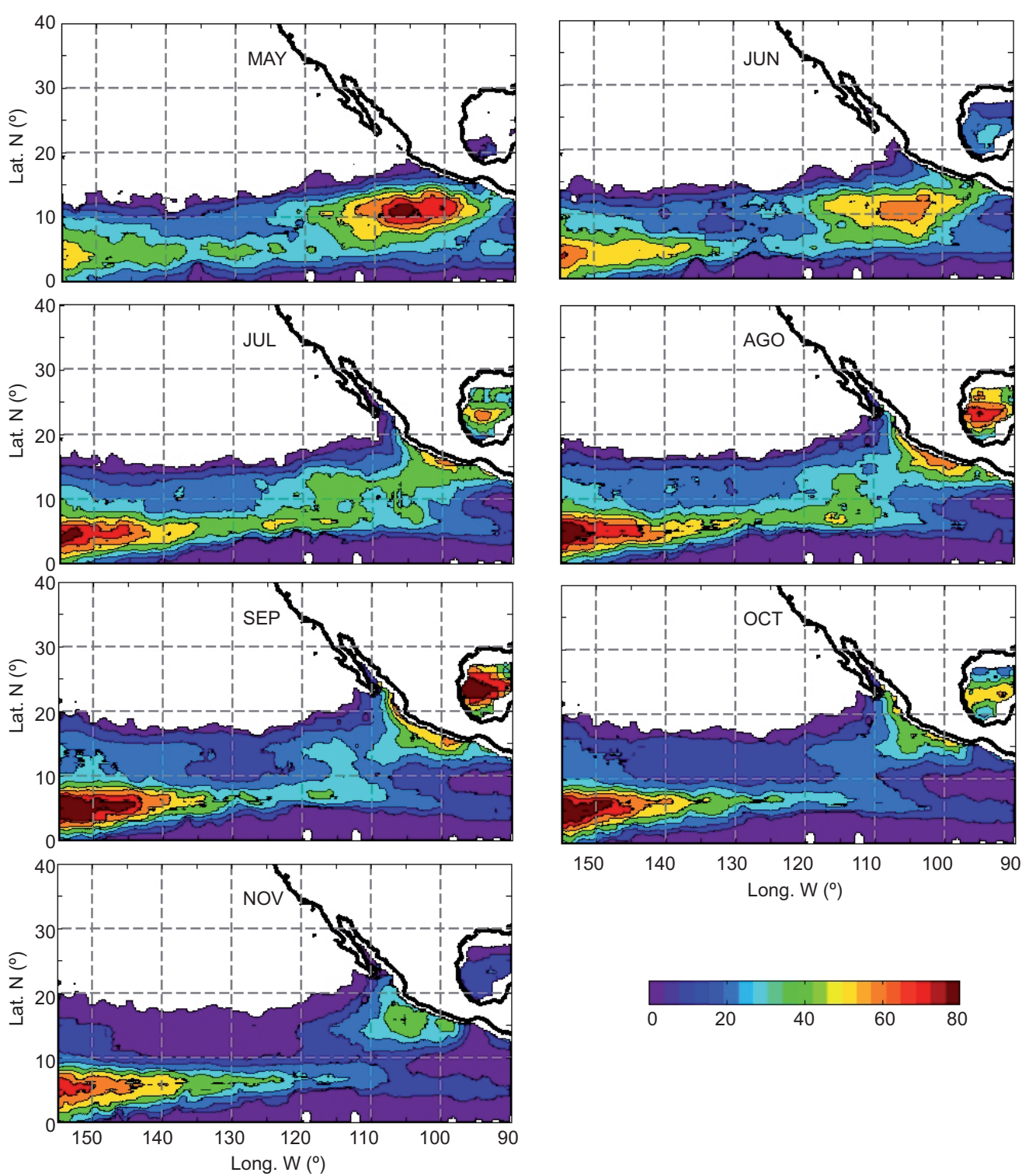

Fig. 1. Monthly climatology (1993-2009) of the ocean heat content during the months that comprise the tropical cyclone season of the northeastern Tropical Pacific $\left(\mathrm{KJ} \mathrm{cm}^{-2}\right)$.

et al. (2008) and Kurkzyn et al. (2012). The OHC reaches the minimum of the season during November, when it appears to be influenced by the presence of anticyclonic oceanic eddies recently generated by high wind events in the gulfs of Tehuantepec and Papagayo.

\section{Joint analysis of best track data, ocean heat content and satellite altimetry}

For the purposes of this study, the presence of an anticyclonic oceanic eddy in the region results in an area with high OHC. In order to analyze if the interaction between TCs and anticyclonic oceanic eddies occurs in the northeastern Tropical Pacific, we used both OHC and SSHA daily maps in combination with best track trajectories of the tropical cyclones that occurred in the basin between 1993 and 2009, verifying if at some point in its trajectory and along its lifetime a TC passed over an area with equivalent $\mathrm{OHC}\left(\mathrm{OHC}_{\mathrm{E}}\right)$ higher than $50 \mathrm{~kJ} \mathrm{~cm}^{-2}$ which also had positive SSHA. When these two conditions are fulfilled, this cyclone is considered as having an interaction with an anticyclonic oceanic eddy. It should be noted that the threshold value of $50 \mathrm{~kJ} \mathrm{~cm}^{2}$ is almost three times the value of the $17 \mathrm{~kJ} \mathrm{~cm}^{2}$ identified by Leipper and Volgenau (1972) 
as the amount of heat needed to be removed from the ocean per day, for a hurricane to maintain its intensity. The concept of equivalent $\mathrm{OHC}$ was introduced by Shay and Brewster (2010) as a variable that incorporates the strength of the thermocline at the base of the oceanic mixed layer using a climatological stratification parameter that allows comparing $\mathrm{OHC}$ in different basins. $\mathrm{OHC}_{\mathrm{E}}$ is given by

$O H C_{E}=O H C \sqrt{N_{\max } / N_{o}}$,

where $O H C$ is the previously defined vertically integrated thermal structure from the surface to the depth of the $26{ }^{\circ} \mathrm{C}$ isotherm, $N_{\max }$ represents the maximum buoyancy frequency across the oceanic mixing layer base, and $N_{0}$ is the reference buoyancy frequency for a given reference density (i.e., temperature and salinity). The climatological stratification parameter was calculated based on climatology from GDEM.

For this analysis, the 6-hourly maps of $\mathrm{OHC}_{\mathrm{E}}$ and SSHA were generated objectively analyzing the daily maps of OHC and SSHA to a regular grid with $0.125^{\circ}$ spacing in latitude-longitude, along the lifetime of each TC in the dataset from 1993 to 2009. A mean value calculated in a square area of $1 \times 1^{\circ}$ centered in the TC position at each time step was determined from the $\mathrm{OHC}_{\mathrm{E}}$ and $\mathrm{SSHA}$ values extracted from the 6-hourly maps. This square area of $1 \times 1^{\circ}$ was determined to include the eyewall of most of the TCs in the dataset.

Figure 2 shows an example of the analysis using instantaneous maps of SSHA and $\mathrm{OHC}_{\mathrm{E}}$ and the extracted time series for each variable along the track of hurricane Hilary (1993). It shows a clear interaction with a region with high values of $\mathrm{OHC}_{\mathrm{E}}$ enhanced by the presence of two anticyclonic oceanic eddies. Those eddies were formed in the Gulf of Tehuantepec and off the coast of Guerrero in mid-July and had propagated westward to its current position, confirmed by reviewing daily satellite-derived SSHA data and its calculated surface geostrophic circulation (not shown).

By applying the methodology described in this section to all named tropical cyclones that developed within the region between 90 and $145^{\circ} \mathrm{W}(242$ from 1993 to 2009) we found that 177 of those cyclones $(73 \%)$ presented interaction with an area of $\mathrm{OHC}_{\mathrm{E}}$ enhanced by the presence of anticyclonic oceanic eddies. This kind of interaction was found in all of
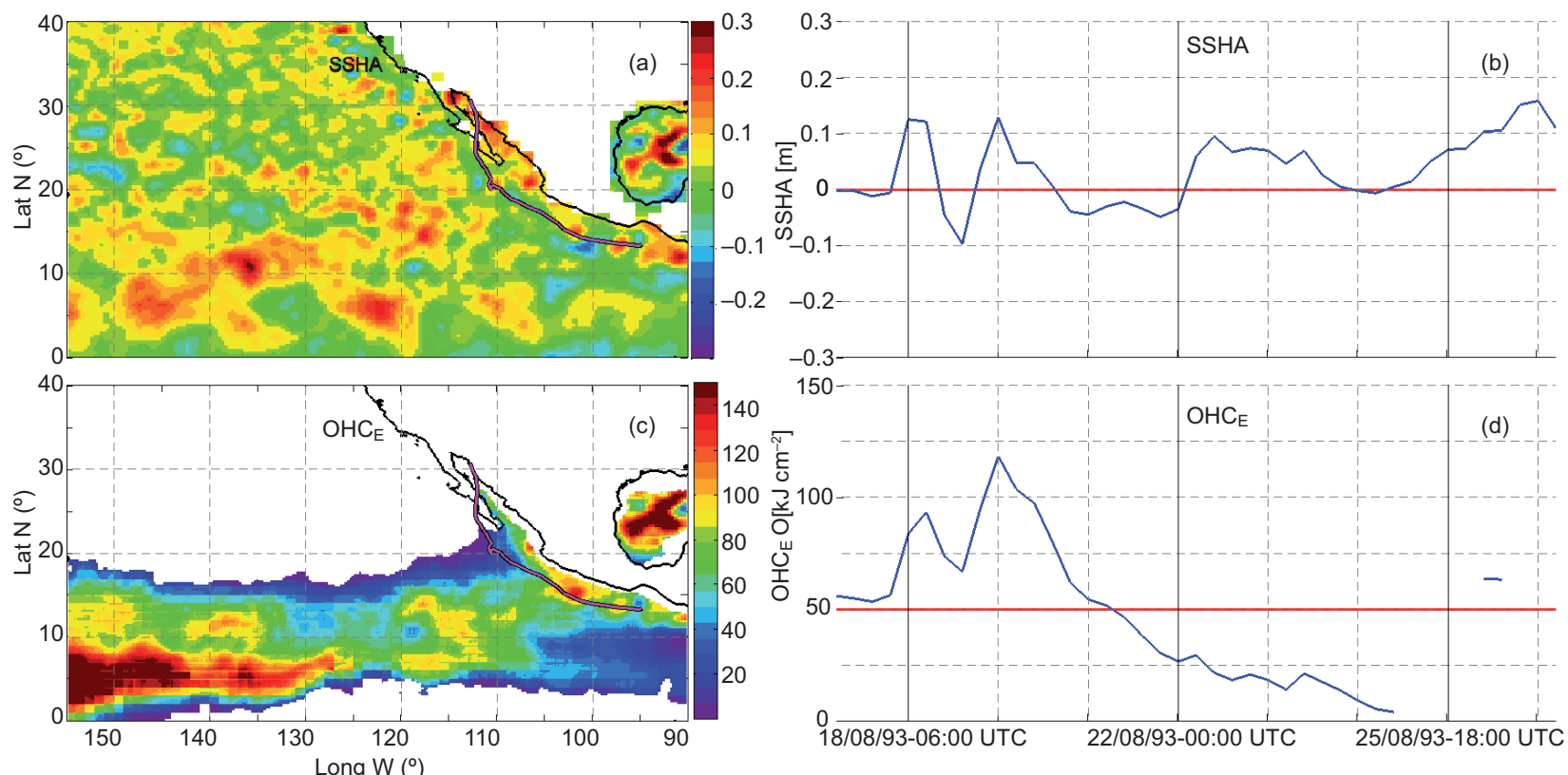

Fig. 2. Equivalent ocean heat content $\left(\mathrm{kJ} \mathrm{cm}^{-2}\right)$ calculated by the two-layer model approach (c), using SSHA (m) data from AVISO (a) and SST from Reynolds for hurricane Hilary on August 17, 1993 during its interaction with a region of locally enhanced ocean heat content due to the presence of two anticyclonic oceanic eddies. Time series of SSHA (b) and $\mathrm{OHC}_{\mathrm{E}}(\mathrm{d})$ along the hurricane track and its lifetime are also presented; the red line indicates the thresholds applied for each variable. 
the 17 analyzed seasons. Note that in 13 of those 17 seasons, the number of TCs that interacted with an anticyclonic oceanic eddy exceeds the number of TCs with no interaction.

Figure 3 presents a summary of the basic statistics of the maximum value of $\mathrm{OHC}_{\mathrm{E}}$ found by the $177 \mathrm{TCs}$ that experienced an interaction with anticyclonic oceanic eddies, categorizing them by its Saffir-Simpson intensity scale. As expected, we found that the larger intensities are related with larger values of $\mathrm{OHC}_{\mathrm{E}}$. Cat-3 hurricanes presented the larger outlier case in this subset of storms $\left(231.29 \mathrm{~kJ} \mathrm{~cm}^{-2}\right)$, related with hurricane Alma (May 24 to June 1, 2002).

When considering only major hurricanes (categories 3, 4 and 5) we found that:

i. The total number of major hurricanes observed during the analyzed period was 61 .

ii. Fifty five $(90 \%)$ of them had experienced an interaction with an area of $\mathrm{OHC}_{\mathrm{E}}$ enhanced by the presence of anticyclonic oceanic eddies.

\section{Rapid and explosive deepening tropical cy- clones}

The minimum sea level central pressure reported on the NHC best track dataset at a 6-h interval was

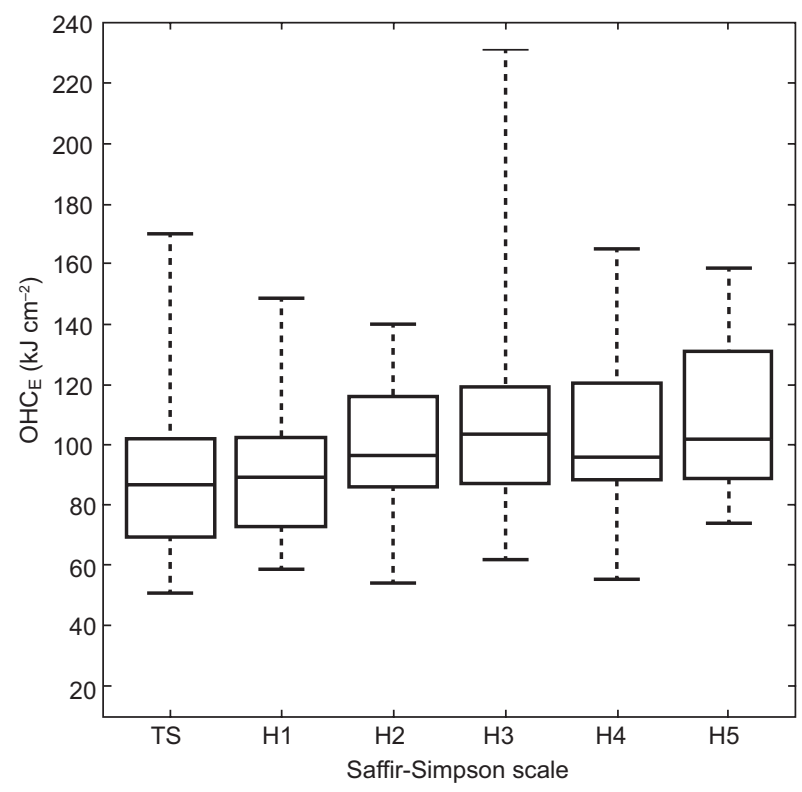

Fig. 3. Summary of equivalent ocean heat content $\left(\mathrm{kJ} \mathrm{cm}^{-2}\right)$ variability calculated for the $177 \mathrm{TCs}$ that have presented interaction with anticyclonic oceanic eddies in the northeastern Tropical Pacific. used to identify tropical cyclones that experienced rapid deepening $(\mathrm{RD})$ or explosive deepening (ED) in the northeastern Tropical Pacific between 1993 and 2009 . The deepening rate $(d p / d t)$ was calculated using forward differences for every time step, for each named tropical cyclone in the selected period. TCs with a deepening rate equal or lower than $-1.75 \mathrm{hPa} / \mathrm{h}$ (or $-42 \mathrm{hPa}$ during $24 \mathrm{~h}$ ) were classified as RD and TCs with deepening rates equal or lower than $-2.5 \mathrm{hPa} / \mathrm{h}$ for at least $12 \mathrm{~h}$ and/or equal or lower than $-5 \mathrm{hPa} / \mathrm{h}$ for at least $6 \mathrm{~h}$ were classified as ED. As an example, Figure 4 shows the evolution of the central pressure and the deepening rate calculated for hurricane Elida (Fig. 4a) in 2002 and for hurricane Linda in 1997 (Fig. 4b).

Forty-three of the 242 tropical cyclones analyzed in the period 1993-2009 (17.7\%), reached the RD criteria and eight (3.3\%) the ED criteria (Fig. 5). Sixteen out of the 17 seasons analyzed had at least one tropical cyclone that reached one of the deepening criteria. The only season that did not have any tropical cyclone experiencing RD or ED was 1999, which together with 1996 are the most inactive seasons in the analyzed record (when only nine cyclones developed for each season). Table II shows a summary of the characteristics of tropical cyclones that underwent ED; note that all of them reached the category of major hurricanes.

\section{Assessment of atmospheric environmental parameters}

Inspired on the environmental parameters originally described by Gray (1975) as cyclogenesis precursors, we calculated the following parameters for analysis:

1. Vertical shear of the horizontal wind between the lower $(850 \mathrm{hPa})$ and upper troposphere $(200 \mathrm{hPa})$.

2. Middle troposphere relative humidity $(550 \mathrm{hPa})$.

3. Vertically integrated relative humidity (from 550 to $1000 \mathrm{hPa}$ ).

These parameters were determined from the publicly-available NARR dataset with a horizontal grid spacing of $32 \mathrm{~km}$ and a time spacing of $3 \mathrm{~h}$, in 29 vertical levels (Mesinger et al., 2005). The vertical profile of the relative humidity (from 550 to $1000 \mathrm{hPa}$ ) was compared with a reference value of $75 \%$ in order to estimate its anomaly. This value was selected 

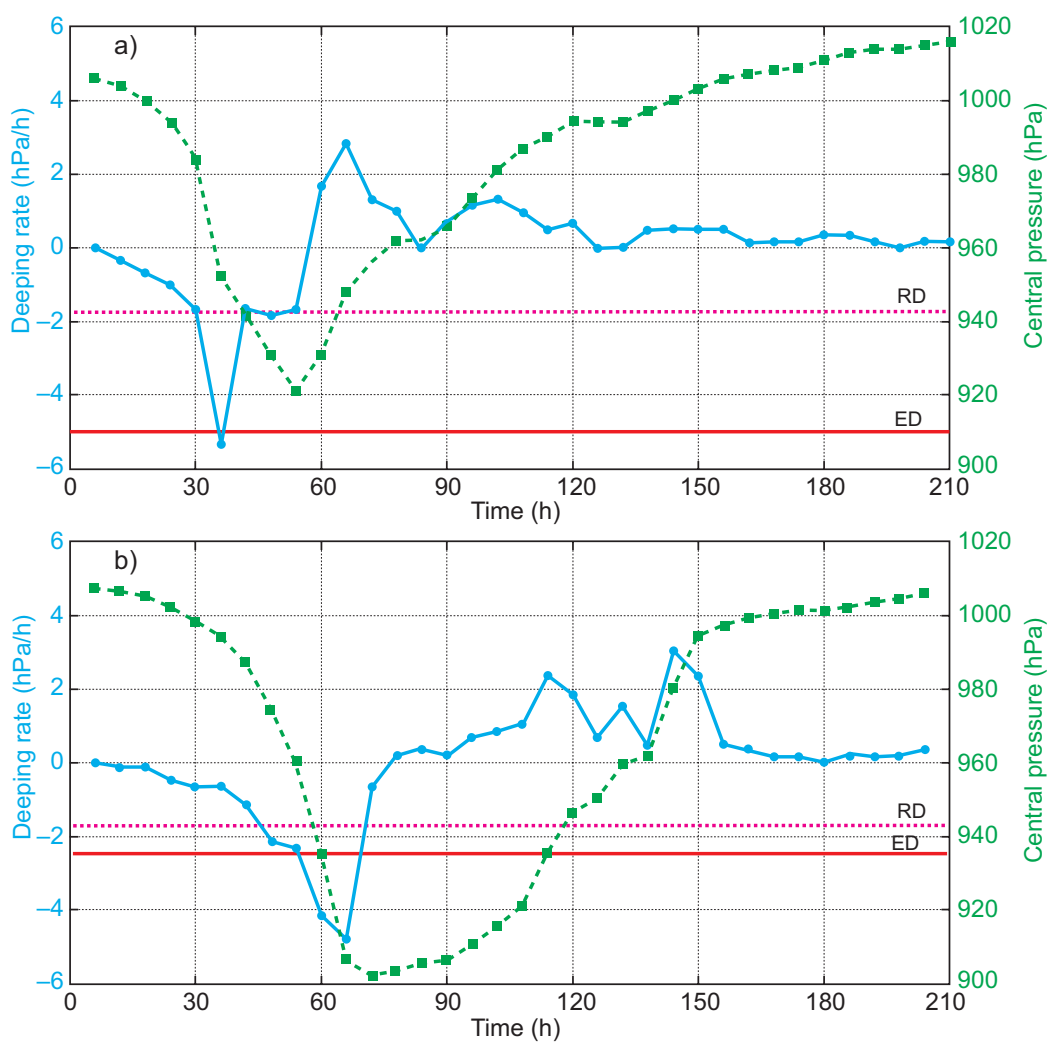

Fig. 4. Central pressure (dashed green line, right scale) and deepening rate (solid blue line, left scale) evolution for tropical cyclones (a) Elida (2002) and (b) Linda (1997). The dashed magenta horizontal line indicates the RD criteria threshold $(-1.75 \mathrm{hPa} / \mathrm{h})$, the horizontal red line (in b) indicates the ED criteria threshold $(-2.5 \mathrm{hPa} / \mathrm{h}$ for at least $12 \mathrm{~h})$ and the solid horizontal red line (in a) the ED criteria threshold $(-5 \mathrm{hPa} / \mathrm{h}$ for at least $6 \mathrm{~h})$.

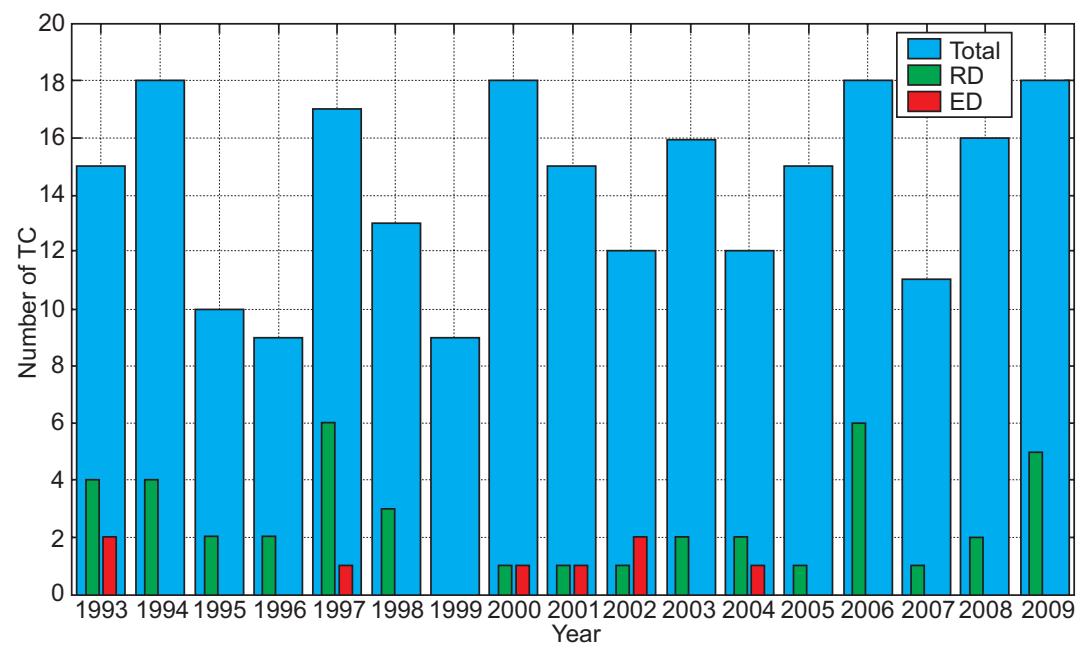

Fig. 5. Frequency distribution of the total number of tropical cyclones (242, in blue), number of tropical cyclones reaching the RD criteria (43, in green), and number of tropical cyclones reaching the ED criteria (8, in red). 
Table II. Hurricanes that experienced explosive deepening in the northeastern Tropical Pacific basin in the period 1993-2009.

\begin{tabular}{lcl}
\hline Name & Season & Comments \\
\hline Kenneth & 1993 & Category 4, second most intense of the season \\
Lidia & 1993 & Category 4, third most intense of the season \\
Linda & 1997 & Category 5, most intense ever in the basin \\
Carlotta & 2000 & Category 4, most intense of the season \\
Juliette & 2001 & Category 4, most intense of the season \\
Elida & 2002 & Category 5, third most intense of the season \\
Kenna & 2002 & Category 5, most intense of the season \\
Howard & 2004 & Category 4, second most intense of the season \\
\hline
\end{tabular}

just below the value used by Emanuel et al. (1986) in their numerical experiments. As indicated in the example in Figure 6, the positive values (humidity values larger than $75 \%$ ) and negative values (humidity values smaller than $75 \%$ ) were determined from the profiles every $6 \mathrm{~h}$, during the lifetime of all $\mathrm{RD} /$ ED hurricanes in the dataset. An example (Adolph, 2001) of this vertical profile and the integrated areas, representing relatively dry (light grey) and humid (dark grey) air in the environment surrounding the hurricane system is presented in Figure 6. These two variables (dry and humid air) are reported in this study as percentage coverage of the indicated dry and humid areas in the figure.

For all the described atmospheric environmental parameters, we calculated the time evolution of the mean value in a 4 by $4^{\circ}$ box (as in Marín et al., 2009) centered at the current location of the cyclone, for all the RD/ED TC in the analyzed period.

Figure 7 shows the time series for all the environmental parameters described in this section for hurricane John (2006). It also shows the time series for central pressure (from the best track dataset) and for $\mathrm{OHC}_{\mathrm{E}}$ and SSHA derived as described in section 4. Note that all the atmospheric parameters were favorable in this case: wind shear in the order of $11 \mathrm{~ms}^{-1}$; relative humidity at $550 \mathrm{hPa}$ close to $84 \%$ during the entire lifetime of the hurricane; vertically integrated humid air values around $32 \%$ (near $32 \%$ of the humid area presented a vertical profile larger than $75 \%$ of relative humidity $[\mathrm{RH}]$ ); and dry air values close to zero most of the time (no presence of air with $\mathrm{RH}$ smaller than $75 \%$ along the vertical profile). The $\mathrm{OHC}_{\mathrm{E}}$ values (Fig. 7f) were around $120 \mathrm{~kJ} \mathrm{~cm}$. Each environmental parameter, both atmospheric and oceanic, was normalized to the highest value presented in all the analyzed RD and ED cyclones of the dataset in order to compare different cases. A summary of those values is presented in Table III.

\section{Relationship between the rapid deepening of tropical cyclones and anticyclonic oceanic ed- dies}

So far we have separately analyzed the interaction of TCs with anticyclonic oceanic eddies in the northeastern Tropical Pacific (section 4) and the fraction

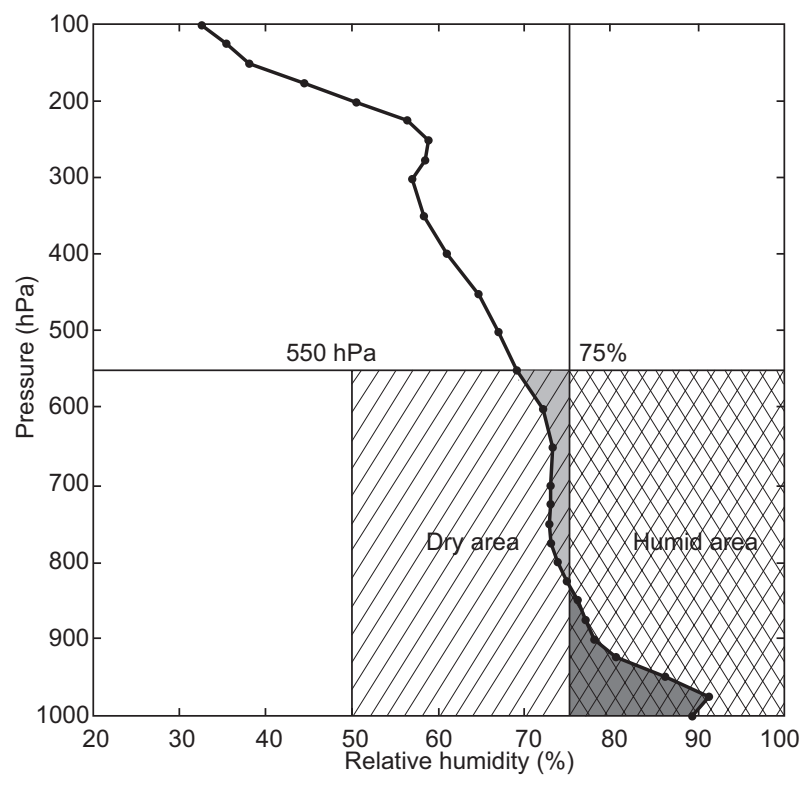

Fig. 6. Relative humidity (\%) profile and its integrated values from 550 to $1000 \mathrm{hPa}$ levels with respect to a reference value of $75 \%$ relative humidity, calculated from NARR for hurricane Adolph at 00:00 UTC (May 30, 2001). The light grey area indicates dry air (with RH less than 75\%) and the dark grey area indicates humid air (RH higher than $75 \%$ ) in the environment surrounding the hurricane. These variables are reported as the percentage coverage of dry area (between 50\%-75\% and 1000-550 hPa) or humid area (between 75\%-100\% and 1000-550 hPa). 


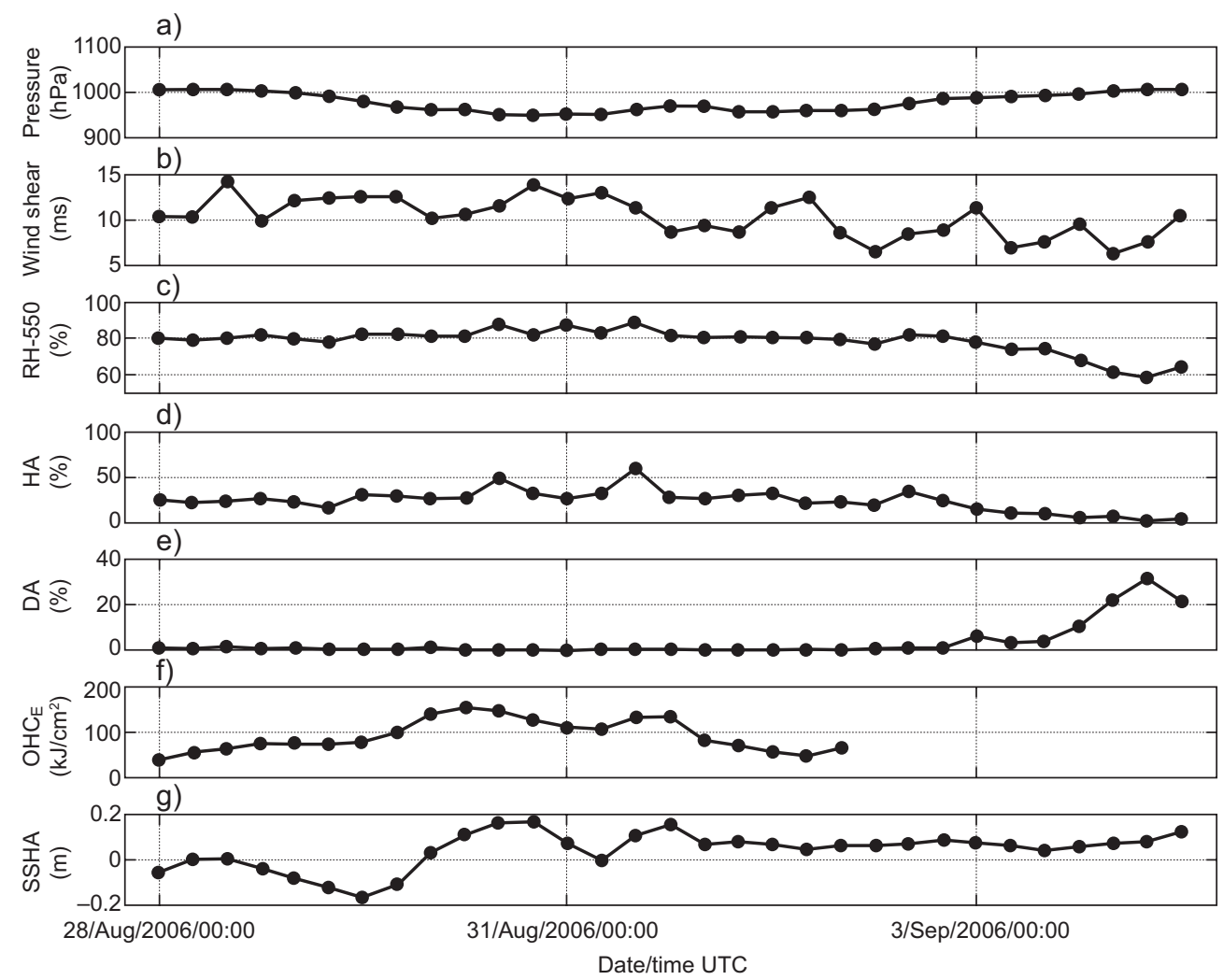

Fig. 7. Time series for (a) central pressure $(\mathrm{hPa})$ as in best track, (b) vertical wind shear $\left(\mathrm{ms}^{-1}\right)$, (c) relative humidity at $550 \mathrm{hPa}(\%)$, (d) vertically integrated humid air (\%), (e) vertically integrated dry air (\%), (f) equivalent oceanic heat content $\left(\mathrm{kJ} \mathrm{cm}^{-2}\right)$ and $(\mathrm{g})$ sea surface height anomaly (m) for hurricane John (2006), the second most intense hurricane during the 2006 season in the northeastern Tropical Pacific.

of TCs in the basin that underwent RD or ED during the same period (section 5). In this section we analyze the atmospheric and oceanographic environmental context in which the RD and/or ED occurred, in order to understand the role of anticyclonic oceanic eddies in the evolution.

As an example, we present here the detailed description of the atmospheric and oceanographic environmental conditions during the lifetime of hurricane Linda (1997), which experienced explosive deepening. Immediately following we generalize the discussion in terms of the statistics for all the analyzed $\mathrm{RD} / \mathrm{ED}$ TCs.

\subsection{Hurricane Linda (1997)}

Hurricane Linda originated from an easterly wave observed in the radiosonde data from Dakar, Senegal, in the west coast of Africa on August 24, 1997 (Lawrence, 1999). The wave was tracked across the Atlantic and the Caribbean Sea in satellite imagery by the NHC. Increased cloudiness and convection off the Pacific coast of Panama on September 6, 1997 was likely associated with that wave. Evidence of a poorly defined cloud system center within a broad tropical disturbance appeared in satellite imagery early on September 9. The region presented very high $\mathrm{OHC}_{\mathrm{E}}$ linked to the presence of several anticyclonic oceanic eddies that had formed along the coast and began to move westward. A banded cloud pattern emerged, and the NHC indicated that a tropical depression formed from the disturbance around 12:00 UTC on September 9, 1997 at about $740 \mathrm{~km}$ south of Manzanillo, Mexico. The tropical cyclone moved northwestward at 2.5 to $5 \mathrm{~ms}^{-1}$, partly in response to a mid- to upper-level low in the vicinity of southern Baja California. Deep convective banding increased and the depression strengthened into tropical storm Linda at 00:00 UTC on September 10, 1997 with maximum winds of $18 \mathrm{~ms}^{-1}$ and minimum central pressure of $1005 \mathrm{hPa}$. 
Table III. Summary of the maximum values reached for the different environmental parameters that have been evaluated for hurricanes that experienced RD or ED in the northeastern Tropical Pacific basin during the period 1993-2009.

\begin{tabular}{|c|c|c|c|c|}
\hline $\begin{array}{l}\text { Environmental } \\
\text { parameter }\end{array}$ & $\begin{array}{l}\text { Maximum } \\
\text { value }\end{array}$ & $\begin{array}{l}\text { Name } \\
\text { of TC }\end{array}$ & Season & Comments \\
\hline RH-550 hPa & $92.71 \%$ & Fernanda & 1993 & $\begin{array}{l}\text { Category } 4 \text {, third most intense of the season. The maximum } \\
\text { value of RH at } 550 \mathrm{hPa} \text { was reached during its weakening (17/ } \\
\text { Aug/1993 at } 06: 00 \mathrm{UTC}) \text {. }\end{array}$ \\
\hline Wind shear & $32.76 \mathrm{~ms}^{-1}$ & Juliette & 1995 & $\begin{array}{l}\text { Category } 4 \text {, most intense of the season. The maximum value } \\
\text { of wind shear was reached during its weakening }(25 / \mathrm{Sept} / 1995 \\
\text { at 00:00 UTC). }\end{array}$ \\
\hline $\mathrm{OHC}_{\mathrm{E}}$ & $154.35 \mathrm{~kJ} \mathrm{~cm}^{-2}$ & Linda & 1997 & $\begin{array}{l}\text { Category } 5 \text {, most intense ever in the basin. The maximum value } \\
\text { of OHCE was reached during its initial intensification stage (10/ } \\
\text { Sept/1997 at 18:00 UTC). }\end{array}$ \\
\hline VI-HA & $79.58 \%$ & Linda & 1997 & $\begin{array}{l}\text { Category } 5 \text {, most intense ever in the basin. The maximum } \\
\text { value of vertically integrated humid air was reached during its } \\
\text { weakening period (16/Sept/1997 at 00:00 UTC). }\end{array}$ \\
\hline VI-DA & $100 \%$ & Howard & 2004 & $\begin{array}{l}\text { Category } 4 \text {, second most intense of the season. The maximum } \\
\text { value of vertically integrated dry air was reached during its } \\
\text { weakening (10/Sept/2004 at 06:00 UTC). }\end{array}$ \\
\hline
\end{tabular}

RH: relative humidity; OHC: ocean heat content; VI-HA: vertically integrated humid air; VI-DA: vertically integrated dry air.

The complete path of Linda is shown in Figure 8a, combined with the spatial distribution of $\mathrm{OHC}_{\mathrm{E}}$ for 12:00 UTC on September 11, 1997. Since 06:00 UTC on this same day, the deepening rate reached values close to the ED threshold $(2.25 \mathrm{hPa} / \mathrm{h})$ and was maintained for $12 \mathrm{~h}$. Subsequently, at 18:00 UTC on September 11, 1997 Linda experienced an episode of ED (with an average deepening rate of $4.5 \mathrm{hPa} / \mathrm{h}$ for $12 \mathrm{~h}$ ). During those $24 \mathrm{~h}$ (indicated in Fig. $8 \mathrm{a}$ by the green circles along Linda's track and in Fig. 8b, c between the black vertical lines) minimum central pressure decreased from 974 to $902 \mathrm{hPa}$ and the wind speed increased from 41.1 to $82.3 \mathrm{~ms}^{-1}$ turning Linda into a category 5 hurricane on the Saffir-Simpson scale and becoming the strongest hurricane ever recorded in the northeastern Tropical Pacific.

As shown in Figure 8c, the atmospheric conditions were very favorable for intensification, with weak vertical shear (around $9.8 \mathrm{~ms}^{-1}$, during the first $72 \mathrm{~h}$ ), very high values of relative humidity in the middle troposphere (around 83\%), with humid air penetration along the entire column (around $40 \%$ ) and almost without any dry air intrusion in the vertical profile (around $0.11 \%$ ). Linda formed in an area with high $\mathrm{OHC}_{\mathrm{E}}$ (around $50 \mathrm{~kJ} \mathrm{~cm}^{-2}$ ) and its trajectory passed through an area with increasingly high $\mathrm{OHC}_{\mathrm{E}}$, during the first $36 \mathrm{~h}$ (reaching the maximum value of $154.35 \mathrm{~kJ} \mathrm{~cm}^{-2}$ ). Its effect is reflected in the near exponential growth of the wind speed time series, and the rapid decrease of the central pressure values, as shown in Figure $8 \mathrm{~b}$. The ED occurs immediately after Linda's trajectory passed over the maximum values of $\mathrm{OHC}_{\mathrm{E}}$, in an area influenced by the presence of anticyclonic oceanic eddies. It is important to note that the values of $\mathrm{OHC}_{\mathrm{E}}$ during the evolution of Linda are the highest encountered in the analyzed TCs that reached RD or ED in the dataset (1993-2009). The weakening of Linda coincides with the decline of the $\mathrm{OHC}_{\mathrm{E}}$ and this factor is clearly decisive, since it never made landfall. Although atmospheric conditions were very favorable for the remainder of the lifetime of the hurricane, even slightly improving (since the $\mathrm{RH}$ at $550 \mathrm{hPa}$ increased up to $90 \%$, the humidity along the vertical column increased to $80 \%$ [also the highest values on the RD/ED dataset] and the shear dropped up to $5 \mathrm{~ms}^{-1}$ ) the hurricane weakened until dissipating. 

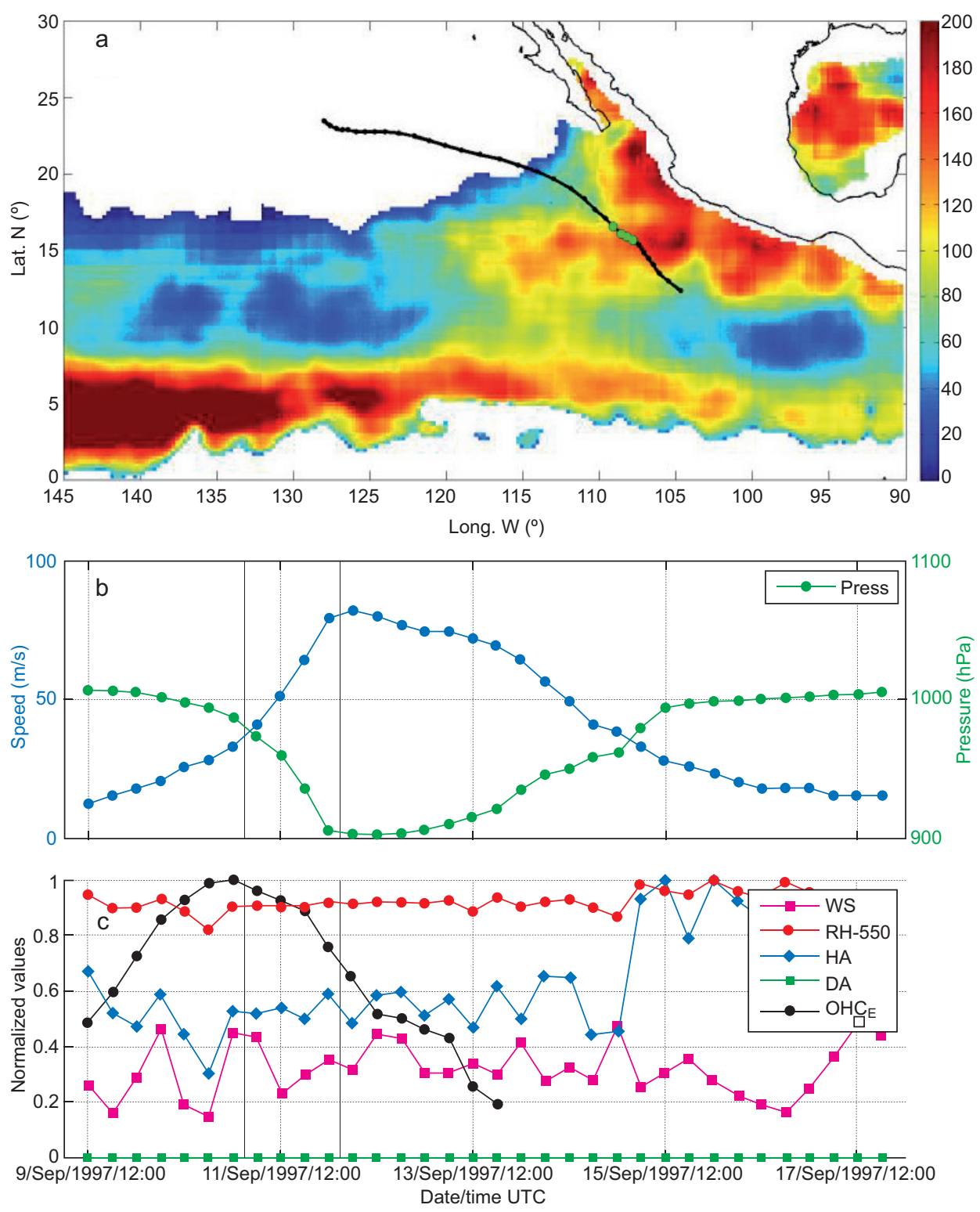

Fig. 8. (a) Objectively analyzed instant field of equivalent ocean heat content $\left(\mathrm{kJ} \mathrm{cm}^{-2}\right)$ and best track trajectory for hurricane Linda (12:00 UTC, September 11, 1997) during its interaction with enhanced $\mathrm{OHC}_{\mathrm{E}}$ by the presence of anticyclonic oceanic eddies. (b) Time series for wind speed (blue line, left scale) and pressure (green line, right scale). (c) Normalized time series of RH at $550 \mathrm{hPa}$ (red line), vertical wind shear at 850-200 hPa (magenta line), dry air intrusion (green line), humid air intrusion (blue line) and equivalent ocean heat content evolution (black line). The green circles in (a) and the black vertical lines in $(b, c)$ highlight the explosive deepening period for Linda.

\subsection{Overall statistical analysis}

When analyzing the environmental parameters for the $51 \mathrm{TCs}$ that experienced RD or ED, we found that in 38 cases $(74 \%)$ the $\mathrm{RD} / \mathrm{ED}$ was directly related with TC interaction with anticyclonic oceanic eddies; interactions had a mean duration of $30 \mathrm{~h}$ and an $\mathrm{OHC}_{\mathrm{E}}$ mean value of $86 \mathrm{~kJ} \mathrm{~cm}^{-2}$. The mean value of SSHA was $0.05 \mathrm{~m}$ and the mean values for atmospheric parameters were as follows: wind shear, $9.5 \mathrm{~ms}^{-1}$; relative humidity at $550 \mathrm{hPa}, 80 \%$; vertically integrated value of humid air, $30 \%$; and vertically integrated value of dry air, $1.6 \%$. 
Those 38 TCs mentioned in the previous paragraph that had experienced RD/ED after their interaction with anticyclonic oceanic eddies, were further analyzed to determine the role of such an interaction in contributing towards reaching the category of major hurricane. The results indicate that in $86 \%$ of the cases (33 out of 38) the system intensified after the interaction to become a major hurricane $(8 \mathrm{H}-5$, $20 \mathrm{H}-4$ and $5 \mathrm{H}-3$ ).

\section{Concluding remarks}

Temporal and spatial variability of the oceanic heat content in the northeastern Tropical Pacific, during the months that comprise the tropical cyclone season for this basin, appears to be closely linked to the presence of anticyclonic oceanic eddies. While the oceanographic community has not yet reached a consensus on the topic, there are a couple of hypotheses for their generation in this basin. Such eddies can be generated in the Gulf of Tehuantepec and the Gulf of Papagayo by the effect of the wind, a forcing mechanism particularly important during the winter months but that can be present also during midsummer. Alternatively, such eddies can be formed by the arrival of downwelling Kelvin coastally-trapped waves that can spawn anticyclonic oceanic eddies during their transit through different regions of the Pacific Coast, from the Gulf of Papagayo to the Gulf of Tehuantepec and northward along the coast of the state of Guerrero. Regardless of the particular generation mechanism, such eddies are often observed in the basin during the months when tropical cyclones form.

In this study we show that in the northeastern Tropical Pacific the interaction between tropical cyclones and anticyclonic oceanic eddies is very common, and we can expect to observe it in most of the tropical cyclones that are generated every single season. We also show that a large majority of the major hurricanes observed in the basin between 1993 and 2009 presented interactions with anticyclonic oceanic eddies.

However, such interaction is not a sufficient condition to induce rapid or explosive deepening of tropical cyclones in the basin, nor is it a sufficient condition to produce major hurricanes. Nevertheless, most of the hurricanes that reached some of the deepening criteria (86\%), reached the category of major hurricane after interacting with areas with high values of OHC. Furthermore, some hurricanes that did not experience rapid deepening also intensified to the category of major hurricane after interacting with areas with high $\mathrm{OHC}$.

It is possible to generalize that anticyclonic oceanic eddies generated in the gulfs of Tehuantepec and Papagayo have a significant impact on the RD and overall intensification of tropical cyclones that develop during July and August in the basin. During September and October, dominant trajectories of tropical cyclones facilitate the interaction with areas of high OHC locally increased by the presence of anticyclonic oceanic eddies generated along the coasts of the northeastern Tropical Pacific by the presence of downwelling Kelvin coastally-trapped waves or other documented physical processes.

Most of the analyzed cases that met the criteria of either RD or ED not only showed interaction with areas of high $\mathrm{OHC}$, but they also showed favorable atmospheric conditions such as low values of wind shear, high values of relative humidity in the mid-troposphere $(550 \mathrm{hPa})$, and high values of vertically-integrated humidity (from 550 to $1000 \mathrm{hPa}$ ).

The heat exchange between the ocean and the hurricane, as it moves through a region with high $\mathrm{OHC}$, locally increased by the presence of anticyclonic oceanic eddies, is not only the most important process in the northeastern Tropical Pacific for a hurricane to reach the rapid or explosive deepening criteria, but also is a key factor for the intensification of tropical cyclones in the basin. Also note that the presence of dry air vertically integrated (with less than $75 \%$ relative humidity values) plays a very important role as an inhibitor for deepening of tropical cyclones in the region, confirming the results reported by Marín et al. (2009) for a few case studies.

The change of tropical cyclone intensity is a complex, nonlinear process that often involves several competing or synergistic factors. However, the results presented here strongly suggest that the variability of the $\mathrm{OHC}$, partly associated with the presence of anticyclonic oceanic eddies and likely with downwelling Kelvin coastally-trapped waves under a favorable atmospheric environment, significantly impact the physical processes controlling cyclogenesis, maintenance and intensity changes of tropical cyclones in the northeastern Tropical Pacific.

\section{Acknowledgments}

This work was carried out with the aid of the Inter-American Institute for Global Change Research (IAI, Grant 
CRN II-048), which is supported by the U.S. National Science Foundation (Grant GEO-0452325). This work was also supported by a scholarship from CONACyT for FO. The authors want to thank Benjamín Jaimes, Jorge Zavala and Luis Zamudio for valuable reviews and comments to previous versions of this paper.

\section{References}

Chang S. and R. Anthes, 1978. Numerical simulations of the ocean's nonlinear baroclinic response to translating hurricanes. J. Phys. Oceanogr. 8, 468-480.

Chelton D. B., M. G. Schlax, R. M. Samelson and R. A. de Szoeke, 2007. Global observations of large oceanic eddies. Geophys. Res. Lett. 34, L15606, doi:10.1029/2007GL030812.

Chelton, D. B., M. G. Schlax and R. M Samelson, 2011. Global observations of nonlinear mesoscale eddies. Prog. Oceanogr. 91, 167-216.

Davis M. A. S., G. M. Brown and P. Leftwich, 1984. A tropical cyclone data tape for the eastern and central North Pacific basins, 1949-1983: Contents, limitations and uses. NOAA Technical Memorandum NWS NHC 25, Coral Gables, Florida.

Emanuel K. A., 1986. An air-sea interaction theory for tropical cyclones. Part 1: Steady-state maintenance. J. Atmos. Sci. 43, 585-605.

Fisher E. L., 1958. Hurricanes and the sea-surface temperature field. J. Meteor. 15, 328-333.

Goni G. J., S. Kamholz, S. L. Garzoli and D. B. Olson, 1996. Dynamics of the Brazil/Malvinas confluence based on inverted echo sounders and altimetry. $J$. Geophys. Res. 95, 22103-22120.

Goni G. J. and J. Trinanes, 2003. Ocean thermal structure monitoring could aid in the intensity forecast of tropical cyclones. EOS T. Am. Geophys. Un. 85, doi:10.1029/2003EO510001.

Gray W. M., 1975. Tropical cyclone genesis. Department of Atmospheric Science Paper No. 234, Colorado State University, Fort Collins, Co.

Hong X., S. W. Chang, S. Raman, L. K. Shay and R. Hodur, 2000. The interaction between hurricane Opal (1995) and a warm core ring in the Gulf of Mexico. Mon. Wea. Rev. 128, 1347-1365.

Jaimes B. and L. K. Shay, 2009. Mixed layer cooling in mesoscale oceanic eddies during hurricanes Katrina and Rita. Mon. Wea. Rev. 137, 4188-4207.

Kessler W. S., 2006. The circulation of the eastern Tropical Pacific: A review. Prog. Oceanogr. 69, 181-217, doi:10.1016/j.pocean.2006.03.009.
Kurczyn J. A., E. Beier, M. F. Lavin and A. Chaigneau, 2012. Mesoscale eddies in the northeastern Pacific tropical-subtropical transition zone: Statistical characterization from satellite altimetry. J. Geophys. Res. 117, C10021, doi:10.1029/2012JC007970.

Kundu P. K., 1990. Fluid mechanics. Academic Press International, $253 \mathrm{pp}$.

Lawrence M. B., 1999. Eastern North Pacific hurricane season of 1997. Mon. Wea. Rev. 127, 2440-2454.

Leipper D. F., 1967. Observed oceanic conditions and hurricane Hilda, 1964. J. Atmos. Sci. 24, 182-196.

Leipper D. and D. Volgenau, 1972. Hurricane heat potential of the Gulf of Mexico. J. Phys. Oceanogr. 2, 218-224.

Lin I.-I., C. C. Wu, K. A. Emanuel, I. H. Lee, C. R. Wu and I. F. Pun, 2005. The interaction of supertyphoon Maemi (2003) with a warm ocean eddy. Mon. Wea. Rev. 133, 2635-2649.

Mainelli M. M., 2000. On the role of the upper ocean in tropical cyclone intensity change. M.Sc. Thesis, University of Miami, $73 \mathrm{pp}$.

Marín J., D. Raymond and G. Raga, 2009. Intensification of tropical cyclones in the GFS model. Atmos. Chem. Phys. 9, 1407-1417.

Mesinger F., G. DiMego, E. Kalnay, K. Mitchell, P. C. Shafran, W. Ebisuzaky, D. Jovic, J. Woollen, E. Rogers, E. H. Berbery, M. B. Ek, Y. Fan, R. Grumbine, W. Higgins, H. Li, Y. Lin, G. Manikin, D. Parrish and W. Shei, 2005. North American Regional Reanalysis. B. Am. Meteorol. Soc. 87, 343-360.

Miller B. I., 1958. On the maximum intensity of hurricanes. J. Meteor. 15, 184-195.

O'Brien J. J. and R. O. Reid, 1967. The non-linear response of a two-layer ocean to a stationary axially symmetric hurricane: Part I. Upwelling induced by momentum transfer. J. Atmos. Sci. 24, 205-215

Palacios D. M. and S. J. Bograd, 2005. A census of Tehuantepec and Papagayo eddies in the northeastern Tropical Pacific. Geophys. Res. Lett. 32, L23606, doi:10.1029/2005GL024324.

Palmen E., 1948. On the formation and structure of tropical cyclones. Geophysica 3, 26-38.

Pantoja D. A., S. G. Marinone, A. Parés-Sierra and F. Gómez-Valdivia, 2012. Numerical modeling of seasonal and mesoscale hydrography and circulation in the Mexican Central Pacific. Cienc. Mar. 38, 363-379.

Perlroth I., 1967. Hurricane behavior as related to oceanographic environmental conditions. Tellus 19, 258-268. 
Reynolds R. W., N. A. Rayner, T. M. Smith, D. C. Stokes and W. Wang, 2002. An improved in situ and satellite SST analysis for climate. J. Climate 15, 1609-1625.

Robinson A. R. (Ed.), 1983. Eddies in marine sciences, Springer, New York, 609 pp.

Shay L. K., G. J. Goni and P. G. Black, 2000. Effects of a warm oceanic feature on hurricane Opal. Mon. Wea. Rev. 128, 1366-1383.

Shay L. K. and J. K. Brewster, 2010. Oceanic heat content variability in the eastern Pacific Ocean for hurricane intensity forecasting. Mon. Wea. Rev. 138, 2110-2131.

Teague W. J., M. J. Carron and P. J. Hogan, 1990. A comparison between the Generalized Digital Environmental Model and Levitus climatologies. J. Geophys. Res. 95, 71677183.

Zamudio L., A. P. Leonardi, S. D. Meyers and J. J. O’Brien, 2001. ENSO and eddies on the southwest coast of Mexico. Geophys. Res. Lett. 28, 13-16.
Zamudio L., H. E. Hurlburt, E. J. Metzger, S. L. Morey, J. J. O'Brien, C. E. Tilburg and J. Zavala-Hidalgo, 2006. Interannual variability of Tehuantepec eddies. J. Geophys. Res. 111, C05001, doi:10.1029/ 2005JC003182.

Zamudio L., H. E. Hurlburt, E. J. Metzger and C. E. Tilburg, 2007. Tropical wave-induced oceanic eddies at Cabo Corrientes and the María Islands, Mexico. J. Geophys. Res. 112, C05048, doi:10.1029/ 2006JC004018.

Zamudio L., P. Hogan and E. J. Metzger, 2008. Summer generation of the southern Gulf of California eddy train. J. Geophys. Res. 113, C06020, doi:10.1029/ $2007 \mathrm{JC} 004467$. 